\author{
Jurnal Kumara Cendekia \\ https://jurnal.uns.ac.id/kumara
}

\title{
PENERAPAN PERMAINAN LARI ESTAFET MODIFIKASI UNTUK MENINGKATKAN KOMPETENSI MOTORIK ANAK USIA 5-6 TAHUN
}

\author{
Khontri Aminatun', Upik Elok Endang Rasmani ${ }^{1}$, Muhammad Munif Syamsuddin ${ }^{1}$ \\ ${ }^{1}$ Pendidikan Guru Pendidikan Anak Usia Dini, Universitas Sebelas Maret
}

E-mail: khontriaminatun@gmail.com, upikelok@staff.uns.ac.id,wandamunif@staff.uns.ac.id

\begin{abstract}
ABSTRAK
Kompetensi motorik merupakan aspek penting yang harus dikembangkan pada anak usia dini sebagai persiapan pada kompetensi selanjutnya. Kompetensi motorik dapat dikembangkan melalui permainan lari estafet modifikasi. Penelitian ini bertujuan untuk meningkatkan kompetensi motorik anak usia 5-6 tahun melalui penerapan permainan lari estafet modifikasi. Penelitian ini merupakan penelitian tindakan kelas dengan pendekatan kuantitatif dan kualitatif. Sumber data dalam penelitian ini adalah anak dan guru. Teknik pengumpulan data dilakukan melalui unjuk kerja, observasi, wawancara dan dokumentasi. Teknik uji validitas data menggunakan triangulasi sumber dan triangulasi teknik. Hasil penelitian menunjukkan bahwa melalui penerapan permainan lari estafet modifikasi terdapat peningkatan pada kompetensi motorik anak yaitu pada pratindakan sebesar 47\%, siklus I sebesar 60\% dan siklus II sebesar 87\%. Peningkatan tersebut dapat dibuktikan dengan keberhasilan anak dalam kompetensi motorik seperti berlari pada jalur zig-zag, melompat pada bidang engklek dan berjalan maju pada garis lurus. Berdasarkan uraian tersebut dapat ditarik kesimpulan bahwa melalui penerapan permainan lari estafet modifikasi dapat meningkatkan kompetensi motorik anak usia 5-6 tahun.
\end{abstract}

Kata Kunci : Kompetensi motorik, lari estafet modifikasi, anak usia 5-6 tahun

\section{ABSTRACT}

Motor competence is an important aspect that must be developed in early childhood as preparation for further competencies. Motor competence can be developed through modified relay running games. This study aims to improve motor competence in children aged 5-6 years TK Pertiwi 02 Gedong Karanganyar through the application of modified relay running games. This research employed Classroom Action Research (CAR) was quantitative and qualitative approach. The data sources in this study were children and teacher. Data collection techniques are carried out using performance methods, observation, interviews and documentation. The data validity tes technique used was source triangulation and technical triangulation. The result of the study showed that through the application of the modified relay running gamehas an increase in the child's motor competence in the pre-action was $47 \%$, in cycle I was $60 \%$ and in cycle II was $87 \%$. This increase was proved by the child's success in motor competence such as running on the zig-zag track, jumping on the crank and going forward in a straight line. Based on the data above, it can be concluded that through the application of modified relay running games can improve children's motor competence aged 5-6 years.

Keywords: Motor competence, run modification relay, children aged 5-6 years 


\section{PENDAHULUAN}

Anak usia dini berkembang dengan cepat dan berurutan melalui tonggak motorik. Anak yang sehat secara fisik maupun mental akan nampak sangat aktif pada geraknya. Gerakan pada anak tersebut akan ditunjukkan melalui berbagai variasi seperti berjalan, merangkak, melompat, berlari dan sebagainya. Aktivitas gerak pada anak banyak dijumpai pada saat mereka bermain bersama teman sepermainannya di taman bermain maupun di sekolah. Anak yang memiliki kompetensi motorik yang baik akan mempunyai peluang yang tinggi untuk terlibat pada aktivitas fisik dengan intensitas yang tinggi sehingga bisa terhindar dari penyakit kurang gerak yang dapat menimbulkan biaya banyak untuk kesehatannya.

Penelitian dari Loprinzi, Davis dan Fu (2015) menyatakan bahwa pada masa anak-anak dianggap sebagai aspek penting untuk pengembangan aktivitas fisik yang memadai yang menjadikan anak untuk menikmati setiap aktivitas fisiknya sehingga akan memberikan efek jangka panjang pada kemampuan geraknya. Aktivitas fisik memberikan dampak pada kesehatan dimasa sekarang ataupun masa mendatang. Kompetensi motorik secara tidak langsung dapat mempengaruhi aktivitas fisik melalui peningkatan partisipasi aktivitas fisik. Peningkatan partisipasi aktivitas fisik selama masa kanak-kanak dapat mempengaruhi aktivitas fisik selama tahun-tahun berikutnya (remaja dan dewasa).

Kompetensi motorik berperan penting dalam aspek perkembangan anak dan berhubungan erat dengan kesehatan (Syamsuddin, Pudyaningtyas, \& Parwatiningsih, 2019). Anak-anak yang mempunyai kesehatan dengan baik akan menjadikan anak sehat secara fisik dan lebih terampil dalam melakukan berbagai aktivitas. Anak yang mempunyai kompetensi motorik yang tinggi akan berdampak pula pada kesehatannya.

Hasil observasi yang sudah dilaksanakan peneliti menemukan permasalahan yang nampak pada anak kelompok B yaitu pada indikator kompetensi motorik anak. Indikator tersebut ditunjukkan pada sikap anak yang sering meminta bantuan guru dan anak masih kesulitan dalam melakukan aktivitas fisik bersama temannya. Anak juga lebih sering distimulasi pada kemampuan kognitif dan motorik halus seperti membaca, menulis, berhitung, 
mewarnai. Kompetensi motorik anak terlihat masih perlu dioptimalkan pada saat peneliti melakukan observasi pratindakan pada anak. Ada beberapa aktivitas yang peneliti berikan untuk anak antara lain berlari pada jalur zigzag, melompat pada bidang engklek dan berjalan maju pada sebuah garis.

Berdasarkan permasalahan diatas maka diperlukan suatu solusi. Permainan modifikasi merupakan alternatif yang dapat digunakan untuk meningkatkan kompetensi motorik anak. Permainan yang digunakan dalam penelitian ini adalah permainan olahraga yaitu permainan lari estafet modifikasi. Pelaksanaan permainan olahraga ini disesuaikan dengan tahap perkembangan anak usia dini. Permainan dimodifikasi dengan halang rintang seperti berlari zig zag, melompat pada bidang engklek dan berjalan maju pada garis lurus. Lari estafet dimodifikasi agar sesuai dengan usia dan kebutuhan anak. Permainan modifikasi ini dapat memberikan kesenangan bagi anak dan anak merasa tertantang untuk mengeksplor kemampuan geraknya.

\section{Kompetensi Motorik}

Kompetensi motorik merupakan istilah yang dipahami secara global yang menggambarkan tingkat dimana anak- anak dapat melaksanakan kompetensi motorik sebagai dasar motorik kasar pada masa mendatang. Kompetensi motorik dianggap sebagai elemen penting untuk perkembangan sosial, kognitif dan fisik anak karena pada masa prasekolah ini adalah waktu yang ideal untuk mengembangkan kompetensi motorik mendasar.

Pendapat ahli Haugen dan Johansen (2018) menyatakan kompetensi motorik adalah kemampuan untuk melakukan perilaku motorik yang terampil. Kompetensi ini harus dianggap sebagai aspek penting dari perkembangan selama masa kanakkanak. Penelitian telah menunjukkan bahwa anak-anak dengan kompetensi motorik rendah atau masalah koordinasi beresiko mengalami berbagai kesulitan psikologis dimasa anak-anak maupun dimasa remaja. Gangguan koordinasi secara signifikan berdampak pada kemungkinan keikutsertaan anak dalam aktivitas fisik dan mempengaruhi kinerja keseluruhan pada komponen kebugaran fisik yang berbeda dan juga menyebabkan terjadinya obesitas. Luz, dkk. (2019) mendefinisikan kompetensi motorik sebagai kemampuan seseorang untuk melakukan berbagai aksi atau keterampilan motorik yang melibatkan 
alat gerak dan keterampilan proyeksi objek seperti melempar dan menendang.

Pendapat ahli diatas dapat disimpulkan bahwa kompetensi motorik merupakan suatu aspek penting yang harus dikembangkan sejak dini, dimana pada kompetensi motorik ini anak dapat bergerak menghasilkan pola-pola tertentu yang lebih efektif dan efisien dalam menyelesaikan tugas.

\section{Permainan Lari Estafet Modifikasi}

Permainan merupakan alat untuk anak menjelajahi dunianya sendiri dari yang belum diketahui sampai yang diketahui anak dan dari yang tidak bisa melakukan sampai bisa melakukannya. Pendapat Guthrie (Gustiana, 2011) menyatakan bahwa lari estafet merupakan salah satu nomor lomba lari pada perlombaan atletik dalam pelaksanaannya dilakukan secara bergantian atau berantai. Lari ini dilaksanakan secara bersambung dan bergantian dengan membawa tongkat dimulai dari garis start sampai garis finish. Lari estafet yang dimaksud disini adalah lari estafet yang sudah dimodifikasi sesuai dengan tahap perkembangan anak.

Modifikasi merupakan suatu perubahan dari hal lama ke hal baru (Lutan dalam Gustiana, 2011). Ini berarti terdapat inovasi-inovasi baru dalam lari estafet itu misalnya dari segi bentuk, manfaat, cara penggunaan tanpa menghilangkan karakter semula.

Pendapat diatas dapat disimpulkan bahwa permainan lari estafet modifikasi adalah suatu permainan berantai pada program atletik yang melibatkan kerja sama antar tim yang dimulai dari start sampai finish dengan membawa tongkat untuk diberikan ke teman satu tim dengan jarak tetentu.

\section{METODE PENELITIAN}

Penelitian ini merupakan penelitian tindakan kelas (classroon action research) yang dilakukan dengan dua siklus dan setiap siklusnya dilaksanakan dua kali pertemuan. Penelitian ini menggunakan jenis pendekatan kuantitatif dan kualitatif. Tempat penilitian dilaksanakan di TK Pertiwi 02 Gedong Karanganyar. Subjek pada penelitian ini adalah anak usia 5-6 tahun.

Data yang digunakan meliputi data kuantitatif, berupa hasil penilaian mengenai kompetensi motorik pada anak yang didapat menggunakan rubrik penilaian baik sebelum atau setelah diterapkannya tindakan. Data kualitatif berupa informasi dari hasil observasi dan hasil wawancara dengan guru untuk 
mendapatkan segala bentuk informasi mengenai kompetensi motorik anak sebelum dan setelah dilakukan tindakan.

Sumber data menggunakan sumber data primer dari anak, guru, arsip atau dokumen, buku dan jurnal. Sumber data sekunder berupa foto atau video mengenai aktivitas anak. Teknik pengumpulan data berupa observasi, wawancara, dan dokumentasi. Teknik uji validitasnya menggunakan triangulasi sumber dan triangulasi teknik. Teknik analisis data kuantitatif menggunakan analisis data komparatif, sedangkan teknik analisis data kualitatif dilakukan dengan cara pengumpulan data, reduksi data, penyajian data dan penarikan kesimpulan.

\section{HASIL}

Hasil penelitian menunjukkan bahwa kompetensi motorik anak dari prasiklus, siklus I dan siklus II mengalami peningkatan. Persentase ketuntasan klasikal sebelum tindakan dapat dilihat pada tabel 1 .

Tabel 1. Persentase Ketuntasan Klasikal Anak Sebelum Tindakan

\begin{tabular}{ccc}
\hline Nilai & F & Presentase \\
\hline Tuntas & 7 & $47 \%$ \\
Belum Tuntas & 8 & $53 \%$ \\
Jumlah & 15 & $100 \%$ \\
\hline
\end{tabular}

Berdasarkan tabel diatas dapat dijelaskan bahwa persentase ketuntasan secara klasikal kompetensi motorik anak pratindakan adalah $47 \%$ atau 7 anak yang mendapatkan nilai tuntas dan $53 \%$ atau 8 anak mendapatkan nilai belum tuntas. Hasil skor yang didapatkan belum mencapai target yang ingin dicapai yaitu sebesar $75 \%$ sehingga kompetensi motorik anak masih perlu untuk ditingkatkan. Pelaksanaan siklus I mengalami peningkatan pada setiap indikatornya. Hal ini dapat dilihat tabel persentase ketuntasan secara klasikal kompetensi motorik siklus I berikut ini: Tabel 2. Persentase Ketuntasan Klasikal Anak Siklus I

\begin{tabular}{ccc}
\hline Nilai & F & Persentase \\
\hline Tuntas & 9 & $60 \%$ \\
Belum & 6 & $40 \%$ \\
Tuntas & & \\
\hline Hasil & ketuntasan & kompetensi
\end{tabular}

motorik anak berdasarkan akumulasi dari ketiga indikator yang digunakan sebanyak 9 anak sudah tuntas dan 6 anak belum tuntas. Meskipun hasil sudah menunjukkan adanya peningkatan, namun persentase ketuntasan klasikal belum mencapai target yang sudah ditetapkan yaitu sebesar 75\%. Anakanak terlihat lebih antusias dan bisa dikondisikan untuk memenuhi aturan permainan lari estafet modifikasi tetapi masih terdapat beberapa anak yang 
masih mengalami kebingungan untuk melakukan kegiatan sehingga masih perlu arahan dari guru. Anak yang masih mengalami kebingungan menjadi dasar bagi peneliti dan guru untuk melakukan tindakan pada siklus II dengan berbekal refleksi pada siklus I ini.

Pelaksanaan siklus II mengalami peningkatan setelah adanya perbaikan. Peningkatan dapat dilihat pada tabel persentase ketuntasan secara klasikal kompetensi motorik siklus II berikut ini: Tabel 3. Persentase Ketuntasan Klasikal Anak Siklus II

\begin{tabular}{ccc}
\hline Nilai & F & Persentase \\
\hline Tuntas & 13 & $87 \%$ \\
Belum Tuntas & 2 & $13 \%$ \\
\hline
\end{tabular}

Persentase ketuntasan klasikal siklus II sudah mencapai target yang ditetapkan yaitu sebesar $75 \%$ sehingga penelitian dihentikan pada siklus II. Pada siklus II anak sudah menunjukkan kompetensi motoriknya dengan baik karena telah mencapai target keberhasilan yang sudah ditetapkan peneliti sebesar 75\%. Guru memberikan motivasi dan semangat kepada semua anak terutama kepada anak yang belum mencapai skor ketuntasan. Guru juga akan memberikan pengulangan lebih banyak pada anak yang belum tuntas sehingga bisa didapatkan hasil yang lebih optimal.

Hasil penelitian ini menunjukkan bahwa melalui permainan lari estafet modifikasi dapat meningkatkan kompetensi motorik anak. Perbandingan hasil ketuntasan kompetensi motorik dapat dilihat pada gambar 1 .

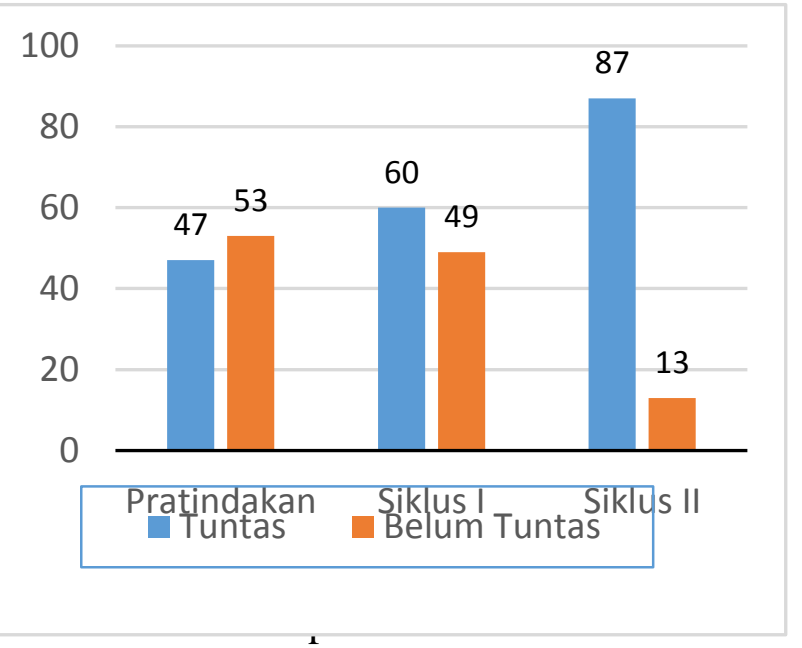

Berdasarkan gambar 1 dapat diketahui bahwa tingkat kompetensi motorik anak mengalami peningkatan. Hasil tersebut terlihat dari data pretest pada saat pratindakan kompetensi motorik anak mencapai nilai sebesar $47 \%$, meningkat pada siklus I menjadi $60 \%$ dan siklus II sebesar $87 \%$. Berdasarkan data tersebut, permainan lari estafet modifikasi dapat meningkatkan kompetensi motorik.

\section{PEMBAHASAN}

Permainan lari estafet modifikasi sebelum diterapkan masih terdapat anak 
yang merasa kesulitan ketika melakukan indikator kompetensi motorik. Indikator yang digunakan pada penelitian ini bersumber dari Utesch, dkk. (2016) dan Sun, dkk. (2010) yaitu berlari pada jalur zig-zag, melompat pada bidang engklek dan berjalan maju pada garis lurus. Berdasarkan hasil penelitian yang telah dilaksanakan dengan menerapkan permainan lari estafet modifikasi pada anak dapat meningkatkan kompetensi motorik anak.

Penemuan ini sejalan dengan Henrique, dkk (2016) yang menyatakan bahwa peningkatan kompetensi motorik dapat dilakukan melalui aktivitas fisik seperti kegiatan olahraga. Hal ini mempunyai hubungan yang dinamis antara kompetensi motorik dengan kegiatan olahraga seperti berlari, berjalan, melompat, dan lain-lain.

Hasil penelitian tindakan kelas pada anak menunjukkan 13 dari 15 anak tuntas pada ketiga indikator. Indikator berjalan maju pada garis lurus merupakan indikator dengan ketuntasan tertinggi, sedangkan indikator melompat pada bidang engklek dengan ketuntasan terendah. Batas ketuntasan rendah dikarenakan pada saat pembelajaran anak sering menghampiri orang tuanya yang menunggu di sekolah, orang tuanya pun kurang memberikan dukungan agar anak mau fokus melakukan permainan lari estafet modifikasi.

Faktor yang mempengaruhi kompetensi motorik anak berasal dari lingkungan keluarga maupun tempat tinggal. Hal ini sesuai dengan pendapat Estevan, dkk (2018) yang menyatakan bahwa orang tua harus memberikan wawasan yang berharga untuk anakanak. Oleh karena itu disarankan bagi orang tua dan guru untuk memberikan contoh kompetensi motorik yang disesuaikan dengan tahap usia anakanak. Faktor kedua berasal dari lingkungan tempat tinggal, hal tersebut dapat diketahui bahwa lingkungan dan budaya setiap daerah berbeda-beda sehingga mempengaruhi kompetensi motorik setiap anak. Setiap daerah memiliki strategi dan kebijakan masingmasing dalam mendorong perkembangan anak. Lingkungan akan sangat berperan penting dalam tumbuh dan berkembangnya anak, terutama pada lingkungan keluarga. Selain itu, anak kurang percaya diri sehingga menyebabkan kurang optimal dalam melakukan gerakan untuk meningkatkan kompetensi motoik anak.

\begin{tabular}{lr}
\multicolumn{2}{c}{ Berdasarkan uraian diatas } \\
peningkatan yang terjadi pada
\end{tabular}


kompetensi motorik anak karena dampak dari penerapan permainan lari estafet modifikasi. Permainan lari estafet modifikasi ini merupakan permainan yang efektif untuk meningkatkan kompetensi motorik. Penerapan pembelajaran pada gerak motorik yang sudah dimodifikasi membuat anak lebih antusias dan bersemangat dalam melakukan berbagai aktivitas fisik pada tahap usia berikutnya. Manfaat dari pengembangan kompetensi motorik ini yaitu tingkat kompetensi motorik yang lebih tinggi terbukti secara positif dapat meningkatkan kemampuan tubuh untuk meningkatkan aktivitas fisik yang lebih intens dan berkesinambungan dengan melibatkan sekelompok otot besar. Kompetensi motorik ini penting untuk meningkatkan kinerja akademik anak dimasa prasekolah dan masa dewasa nantinya dan kompetensi motorik ini dapat mengurangi resiko obesitas atau kelebihan berat badan pada anak.

Temuan lain yang peneliti dapatkan pada penerapan permainan lari estafet modifikasi selain memberikan peningkatan pada kompetensi motorik anak juga memberikan pengaruh pada aspek kognitif dan sosial emosional. Permainan lari estafet modifikasi terdiri dari serangkaian kegiatan yang melibatkan aktivitas fisik, anak harus melakukan kegiatan secara urut sehingga anak harus mengingat dan anak harus fokus selama melakukan pembelajaran.

Permainan lari estafet modifikasi terdapat kegiatan melompat yang dibuat dari media berbentuk lingkaran dan persegi, ketika kegiatan melompat anak harus bisa membedakan rintangan yang berbentuk lingkaran anak melompat dengan satu kaki dan berbentuk persegi anak melompat dengan dua kaki serta dalam melakukan kegiatan anak harus bekerja sama dengan timnya sehingga kemampuan kognitif dan sosial emosional anak juga dioptimalkan melalui permainan modifikasi ini. Maka dapat disimpulkan bahwa selain untuk meningkatkan pada aspek motorik, permainan lari estafet modifikasi juga efektif dalam mengembangkan kemampuan kognitif dan sosial emosional anak. Gustiana (2011) berpendapat bahwa permainan modifikasi dapat digunakan untuk menstimulasi anak pada kemampuan motoriknya dan untuk mengembangkan kemampuan kognitif anak dalam hal berfikir serta kemampuan sosial emosional anak dalam mengendalikan emosinya untuk bekerja sama dengan orang lain. 


\section{SIMPULAN DAN SARAN}

Hasil akhir dari penelitian ini bahwa melalui penerapan permainan lari estafet modifikasi dapat meningkatkan kompetensi motorik anak. Peningkatan kompetensi motorik ditunjukkan dari indikator berlari pada jalur zig zag, melompat pada bidang engklek dan berjalan maju pada garis lurus.

Berdasarkan hasil penelitian dan simpulan, peneliti memberikan saran sebagai berikut:

\section{Bagi Guru}

Guru sebaiknya dapat memberikan kegiatan yang menarik bagi anak dan menyenangkan sehingga anak merasa antusias untuk mengikuti proses pembelajaran. Mengingat kompetensi motorik pada anak itu perlu dilatih sejak dini dalam aktivitas fisik, maka guru dapat menggunakan kegiatan yang melibatkan aktivitas fisik, salah satunya menggunakan permainan lari estafet modifikasi.

\section{Bagi Sekolah}

Pihak sekolah lebih memberikan dorongan dan pengetahuan bagi guru kelas agar lebih memberikan kegiatan yang menarik minat anak dan menyenangkan, namun disesuaikan juga dengan tingkat perkembangan anak.

\section{Bagi Peneliti Lain}

Hasil dari penelitian ini dapat dijadikan referensi guna menyelesaikan permasalahan yang serupa. Penerapan permainan lari estafet modifikasi ini dapat digunakan sebagai contoh bagi penelitian selanjutnya dan dapat dikembangkan lagi sesuai tingkat perkembangan anak yang dapat meningkatkan kompetensi motorik anak. 


\section{DAFTAR PUSTAKA}

Estevan, I., Molina-García, J., Bowe, S. J., Álvarez, O., Castillo, I., \& Barnett, L. M. (2018). Who can best report on children's motor competence: parents, teachers, or the children themselves? Psychology of Sport and Exercise, 34, 1-9.

https://doi.org/10.1016/j.psychsport.2 017.09.002

Haugen, T., \& Johansen, B. T. (2018). Difference in physical fitness in children with initially high and low gross motor competence: a ten-year follow-up study. Human Movement Science, 62(October), 143-149. https://doi.org/10.1016/j.humov.2018. 10.007

Henrique, R. S., Ré, A. H. N., Stodden, D. F., Fransen, J., Campos, C. M. C., Queiroz, D. R., \& Cattuzzo, M. T. (2016). Association between sports participation, motor competence and weight status: a longitudinal study. Journal of Science and Medicine in Sport, 19(10), 825-829. https://doi.org/10.1016/j.jsams.2015.1 2.512

Loprinzi, P. D., Davis, R. E., \& Fu, Y. C. (2015). Early motor skill competence as a mediator of child and adult physical activity. Preventive Medicine Reports, 2, 833-838. https://doi.org/10.1016/j.pmedr.2015. 09.015

Luz, C., Cordovil, R., Rodrigues, L. P., Gao, Z., Goodway, J. D., Sacko, R. S., Stodden, D. F. (2019). Motor competence and health-related fitness in children: a cross-cultural comparison between portugal and the united States. Journal of Sport and Health Science, 8(2), 130-136. https://doi.org/10.1016/j.jshs.2019.01.
005

Syamsuddin, M. M., Pudyaningtyas, A. R., \& Parwatiningsih, S. A. (2019). Kompetensi motorik anak usia dini. Jurnal Ilmiah VISI PGTK PAUD dan Dikmas. 14(2), 123-132. http://doi.org/10.21009/JIV.1402.5

Sun, S., Zhu, Y., Shih, C., Lin, C., \& Wu, S. K. (2010). Development and initial validation of the preschooler gross motor quality scale. Research in Developmental Disabilities, 31, 11871196.

https://doi.org/10.1016/j.ridd.2010.08 .002

Utesch, T., Bardid, F., Huyben, F., Strauss, B., Tietjens, M., De Martelaer, K., Lenoir, M. (2016). Using rasch modeling to investigate the construct of motor competence in early childhood. Psychology of Sport and Exercise, 24, 179-187. https://doi.org/10.1016/j.psychsport.2 016.03.001 